\title{
Clinical and histopathological profile of female genital schistosomiasis
}

\author{
Perfil clínico e histopatológico da esquistossomose genital feminina \\ Perfil clínico e histopatológico de la cistosomiasis genital femenina
}

Received: 05/31/2021 | Reviewed: 06/06/2021 | Accept: 06/10/2021 | Published: 07/04/2021

\author{
Dayvson Moraes Leandro \\ ORCID: https://orcid.org/0000-0001-6704-898X \\ Universidade Federal de Sergipe, Brazil \\ E-mail: dayvsonmoraes@gmail.com \\ Francisco Prado Reis \\ ORCID: https://orcid.org/0000-0002-7776-1831 \\ Universidade Federal de Sergipe, Brazil \\ Universidade Tiradentes, Brazil \\ E-mail: franciscopradoreis@gmail.com \\ José Rodrigo Santos Silva \\ ORCID: https://orcid.org/0000-0002-1918-7122 \\ Universidade Federal de Sergipe, Brazil \\ E-mail: rodrigo.ufs@gmail.com \\ Andrea Ferreira Soares \\ ORCID: https://orcid.org/0000-0002-1442-6462 \\ Universidade Federal de Sergipe, Brazil \\ E-mail: andrea_fsoares@yahoo.com.br \\ Ana Denise Santana de Oliveira \\ ORCID: https://orcid.org/0000-0001-8347-2473 \\ Universidade Federal de Sergipe, Brazil \\ E-mail: ana_costa304@yahoo.com.br \\ Ruan Pablo Vieira Santos \\ ORCID: https://orcid.org/0000-0002-9819-7176 \\ Universidade Federal de Sergipe, Brazil \\ E-mail: pablo_ruanbr@ outlook.com \\ Alisson Matheus Lima Santos \\ ORCID: https://orcid.org/0000-0001-7853-0149 \\ Universidade Federal de Sergipe, Brazil \\ E-mail: alisson.lisso8@gmail.com \\ Vera Lúcia Corrêa Feitosa \\ ORCID: https://orcid.org/0000-0001-5705-6433 \\ Universidade Federal de Sergipe, Brazil \\ E-mail: vera_feitosa@uol.com.br
}

\begin{abstract}
Objective: The present research performed a clinical and histopathological analysis of female genital schistosomiasis (FGS) cases. This was a descriptive and retrospective study, with a quantitative approach based on secondary databases belonging to Memorial Nestor Piva from Universidade Tiradentes. Methodology: Medical records and biopsies from patients affected with genital schistosomiasis (1984-1994) 75 pathology reports were found, biopsies of feminine genitals, with the respective paraffin blocks and slides. In these three search blocks, to contain sufficient quantity of biological material underwent histological new. For pathological analysis, hematoxylin-eosin, picrosirius Red and Masson's trichrome staining were used. A distribution of cases per year was performed to obtain an average and a percentage distribution among the most affected organs. In addition, the chi-square test was used to establish an association between schistosomiasis and its anatomical location and with other pathologies. Results: An average of four cases per year was obtained and the infection was found in all genital system organs, with its highest concentration in the ovaries followed by the uterus. In addition, there was an association between the parasitosis and cervical metaplasia, uterine tumors and salpingitis. In the histopathological analysis, several granulomas containing Schistosoma mansoni eggs, in productive and curing phases, were observed. Conclusion: It was concluded that ovaries were the most affected anatomical sites and that the presence of genital schistosomiasis may favor the occurrence of associated pathologies, thus causing a high morbidity rate to women's health.
\end{abstract}

Keywords: Female Genital Schistosomiasis; Granuloma; Histopathology; Schistosomiasis.

\section{Resumo}

Objetivos: A presente pesquisa realizou uma análise clínica e histopatológica de casos de esquistossomose genital feminina (FGS). Trata-se de um estudo descritivo e retrospectivo, com abordagem quantitativa a partir de bases de 
dados secundárias do Memorial Nestor Piva da Universidade Tiradentes. Metodologia: Prontuários e biópsias de pacientes acometidos por esquistossomose genital (1984-1994) Foram encontrados 75 laudos de patologia, biópsias de órgãos genitais femininos, com os respectivos blocos de parafina e lâminas. Nestes três blocos de busca, para conter quantidade suficiente de material biológico foi submetido a novo histológico. Para a análise patológica, foram utilizadas as colorações por hematoxilina-eosina, picrosirius Red e tricrômico de Masson. Foi realizada a distribuição dos casos por ano para obter uma distribuição média e percentual dos órgãos mais acometidos. Além disso, o teste do qui-quadrado foi utilizado para estabelecer a associação da esquistossomose com sua localização anatômica e com outras patologias. Resultados: Obteve-se em média quatro casos por ano e a infecção foi encontrada em todos os órgãos do sistema genital, com maior concentração nos ovários, seguida do útero. Além disso, houve associação entre a parasitose e metaplasia cervical, tumores uterinos e salpingite. Na análise histopatológica, foram observados vários granulomas contendo ovos de Schistosoma mansoni, nas fases produtiva e de cura. Conclusão: Concluiu-se que os ovários foram os sítios anatômicos mais acometidos e que a presença da esquistossomose genital pode favorecer a ocorrência de patologias associadas, causando, assim, um alto índice de morbidade à saúde da mulher.

Palavras-chave: Esquistossomose Genital Feminina; Granuloma; Histopatologia; Esquistossomose.

\section{Resumen}

Objetivos: La presente investigación realizó un análisis clínico e histopatológico de casos de esquistosomiasis genital femenina (FGS). Se trata de un estudio descriptivo y retrospectivo, con abordaje cuantitativo basado en bases de datos secundarias pertenecientes al Memorial Nestor Piva de la Universidade Tiradentes. Metodología: Registros médicos y biopsias de pacientes afectados de esquistosomiasis genital (1984-1994) Se encontraron 75 informes de patología, biopsias de genitales femeninos, con los respectivos bloques de parafina y portaobjetos. En estos tres bloques de búsqueda, para contener la cantidad suficiente de material biológico se sometieron a nuevos procesos histológicos. Para el análisis patológico se utilizaron tinciones con hematoxilina-eosina, rojo picrosirius y tricrómico de Masson. Se realizó una distribución de casos por año para obtener una distribución promedio y porcentual entre los órganos más afectados. Además, se utilizó la prueba de chi-cuadrado para establecer una asociación entre la esquistosomiasis y su localización anatómica y con otras patologías. Resultados: Se obtuvo un promedio de cuatro casos por año y la infección se encontró en todos los órganos del sistema genital, con su mayor concentración en los ovarios seguidos por el útero. Además, hubo asociación entre parasitosis y metaplasia cervical, tumores uterinos y salpingitis. En el análisis histopatológico se observaron varios granulomas conteniendo huevos de Schistosoma mansoni, en fase productiva y curativa. Conclusión: Se concluyó que los ovarios eran los sitios anatómicos más afectados y que la presencia de esquistosomiasis genital puede favorecer la aparición de patologías asociadas, provocando una alta morbilidad en la salud de la mujer.

Palabras clave: Esquistosomiasis genital feminina; Granuloma; Histopatología; Esquistosomiasis.

\section{Introduction}

Schistosomiasis is a serious parasitic disease with global distribution, being more prevalent in underdeveloped tropical regions, where a considerable part of the population remains living in low-quality socioeconomic and environmental conditions ${ }^{1}$. Uncontrolled densification is another aggravating factor, especially in poor regions of the country, where the lack of access to adequate basic sanitation or public prevention policies makes these places favorable to the occurrence of the parasitic cycle (A. P. de Oliveira et al., 2020).

In most cases, Schistosomiasis mansoni produces severe liver and intestinal damage, portal hypertension and ascites. Such clinical conditions are due to the fact that the parasite settles in the portal system and starts to produce about 300 eggs per day, which are deposited in blood vessels and can reach various organs and tissues, leading to granulomas formation and obstruction of blood vessels. This large number of eggs is the genesis of the schistosomiasis pathophysiology (Brasil, 2014).

Schistosomiasis is a disease that causes high morbidity and low mortality so it is quite neglected (Sousa et al., 2020), this is even more aggravated in relation to its genital form. The literature on the clinical findings of female genital schistosomiasis (FGS) caused by S. mansoni is limited and, in general, such cases are discovered accidentally after invasive clinical procedures, such as laparoscopy and oophorectomy ${ }^{3}$ there is limited literature about the clinical findings of female genital schistosomiasis (FGS) caused by S. mansoni and, in general, such cases are discovered accidentally after invasive clinical procedures, such as laparoscopy and oophorectomy(Poderoso et al., 2008). The time elapsed from clinical care to the start of treatment is long due to the lack of information on FGS in the literature, and the lack of specific diagnosis. We believe that this limitation in the literature is not the only difficulty in diagnosing FGS. There is insecurity in public health services, in addition to the lack of 
integration between Epidemiological surveillance and Primary Care, deficiencies in the management and execution of field actions are also factors of neglect that affect not only the diagnosis of FGS but also other parasites (A. D. S. de Oliveira et al., 2020; S. S. B. da S. Santos \& Melo, 2008).

The diagnosis of schistosomiasis is important for the detection and treatment of the disease in endemic and non-endemic environments. Challenges are found in our environment due to limited resources. Not only the microcopic detection of parasites, but the examination of serum antibodies, detection of antigens and detection of DNA. We know that accurate, economical and easy-to-use diagnostic tests are necessary for the success of control programs in endemic areas (K. G. Weerakoon et al., 2018; K. G. A. D. Weerakoon et al., 2015).

For all these challenges was that Gomes et al (2017) (de Souza Gomes et al., 2017) questioned the rarity or underestimated records of FGS. This is worrying because it is estimated that 6 to $27 \%$ of women with intestinal schistosomiasis, at some point, suffered some histopathological alteration in the genital tract due to the presence of S. mansoni eggs (C. M. A. dos Santos et al., 2019).

Thus, this study Aimed, to better understand and describe the clinical and histopathological profile of female genital schistosomiasis using medical records and biopsy results.

\section{Methodology}

\subsection{Study design}

The study had a descriptive and retrospective design, with a quantitative approach based on the Memorial Prof. Dr. Nestor Piva database, from Tiradentes University, Aracaju, Sergipe, Brazil.

\subsection{Ethical considerations}

This research was carried out after approval by the Ethics Committee on Human Research (CEPE) from Federal University of Sergipe (CAAE: 90898618.5.0000.5546). All items recommended by Resolution 466/12 of the National Council for Ethics in Research (CONEPE) were respected. All participants signed the informed consent to participate in this study. We confirm that all experiments were performed in accordance with relevant guidelines and regulations.

\subsection{Study location and casuistry}

All medical records with female genital schistosomiasis diagnosis, belonging to Memorial Prof. Dr. Nestor Piva from 1974 to 1994, were included. The collected data were arranged in a spreadsheet, containing the variables: anatomical location, symptoms and associated pathologies.

\subsection{Exclusion criteria}

All illegible medical records and biopsies blocks that were not in good condition were excluded.

\subsection{Statistical Analysis}

The number of female genital schistosomiasis cases in the system was distributed per year, with an average for the period analyzed. A linear regression was performed to obtain the $\mathrm{R}^{2}$ value, thus evaluating a possible trend in the cases number over the studied years. The distribution of affected organs from the female genital system was represented in percentage. The chisquare test was used to establish the association between anatomical location, occurrence of pathologies and presence of female genital schistosomiasis. For statistical analysis, free software R was used(Team, 2020). 


\subsection{Analysis by light microscopy}

Of the 75 readable medical records evaluated, only three paraffin blocks with sufficient biological material were selected to obtain new cuts and histopathological examination under light microscopy. The selected blocks contained samples of biopsies from ovary, tubal mucosa and uterus.

\subsection{Histochemical Methods}

For histochemical examination, $5 \mu \mathrm{m}$ sections were obtained and stained by hematoxylin-eosin, picrosirius red and Masson's trichrome methods (Behmer \& Tolosa, 2003).

The presence of collagen tissue and its spatial distribution in the extracellular matrix of schistosomal granulomas were analyzed through the stained slides.

\subsection{Hematoxylin-eosin staining}

Histological sections $(5 \mu \mathrm{m})$ were deparaffinized, hydrated and stained with Harris' hematoxylin for $4 \mathrm{~min}$, washed and differentiated in $70 \%$ ethanol for $1 \mathrm{~min}$. Then, they were counterstained in eosin solution for $1 \mathrm{~min}$, washed, air dried, clarified in xylol and mounted (Behmer \& Tolosa, 2003).

\subsection{Picrosirius red staining}

After being deparaffinized and hydrated, $5 \mu \mathrm{m}$ sections were stained with a picrosirius red solution (sirius-red f 3B 200 ) at $0.1 \%$ in saturated solution of picric acid for $20 \mathrm{~min}$. Then, they were quickly washed, counterstained with Harris' hematoxylin for 10min and quickly washed (3X). Slides were dehydrated in an increasing series of ethanol solutions, clarified in xylol and mounted (Behmer \& Tolosa, 2003).

\subsection{Masson's trichrome staining}

Tissue sections $(5 \mu \mathrm{m})$ were fixed in Bouin for about $12 \mathrm{~h}$ at room temperature. The material was deparaffinized, washed, stained in Harris' hematoxylin for $5 \mathrm{~min}$ and rewashed. The material was stained by Biebrich Scarlet - Acid Fuchsin for $5 \mathrm{~min}$ and washed for 10min. Then, it was stained with aniline blue solution for $10 \mathrm{~min}$, washed, dehydrated and mounted (Behmer \& Tolosa, 2003).

\subsection{Photographic Documentation}

Slides were analyzed through an optical microscope Nikon Eclipse E200 (40x, 100x and 400x) and images captured by a Nikon video camera attached to it.

\section{Results}

From 1974 to 1994, there was an average of four female genital schistosomiasis cases per year. The linear regression coefficient $\left(\mathrm{R}^{2}=0.16\right)$ showed that there was no significant variation in the number of cases over time (Figure 1$)$. 
Figure 1. Number of female genital schistosomiasis cases from 1974 to 1994. Aracaju - SE, Brazil, 2019.

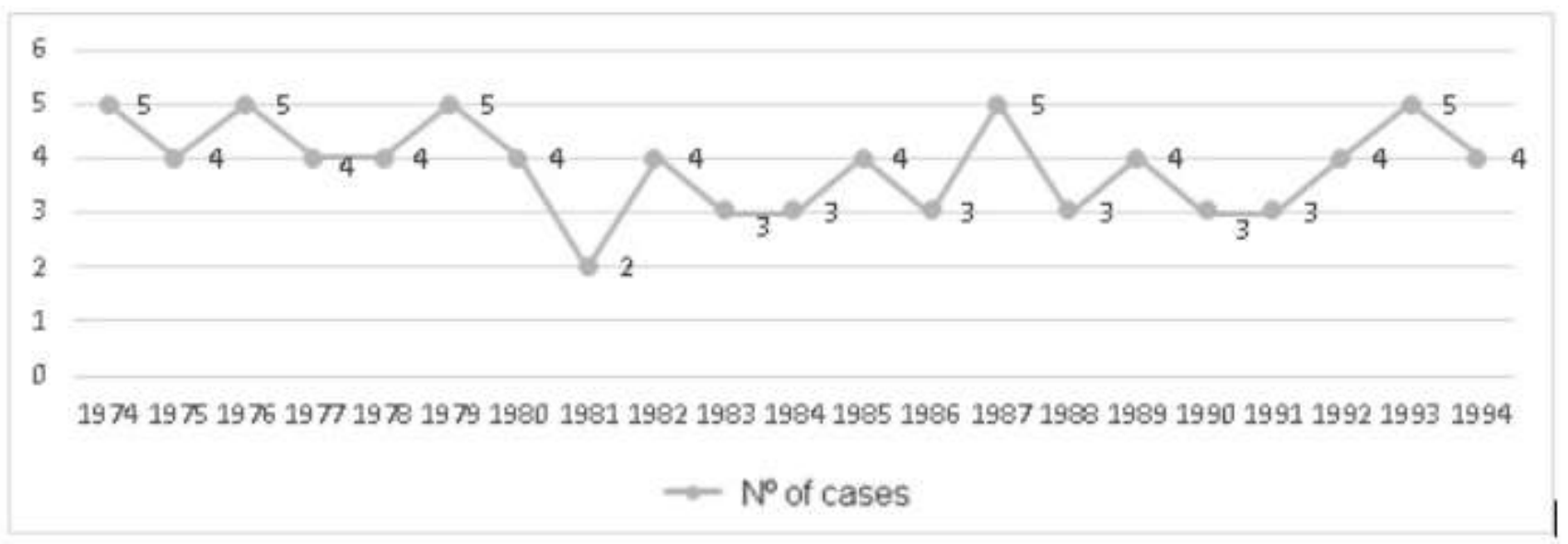

Figure shows the number of female genital schistosomiasis cases from 1974 to 1994. Source: Author's archive.

Among the participants, the most common symptoms were menstrual changes (17\%), lower abdomen pain (13\%) and dyspareunia (4\%). Regarding female genital organs, the ovary was the most affected site (37.3\%), while the vulva was the least affected organ $(2.6 \%)$ (Table 1$)$.

Table 1. Number and frequency (\%) of female genital organs affected by schistosomiasis. Aracaju - SE, Brazil, 2019.

\begin{tabular}{lcc}
\hline Site & $\mathbf{N}$ & $\%$ \\
\hline Ovary & 28 & 37.3 \\
Uterus & 27 & 35.9 \\
Uterine tube & 14 & 18.6 \\
Tube-Ovary & 4 & 5.3 \\
Vulva & 2 & 2.6 \\
Total & 75 & 100.0 \\
\hline
\end{tabular}

Table shows the number and frequency $(\%)$ of female genital organs affected by schistosomiasis. Source: Author's archive.

Among the pathological diagnosis reports with FGS, 18 were also found diagnosis of benign tumors in organs of female genitalia, 11 of these were in the uterus (Table 2).

Table 2 Anatomical location of benign tumors in female genital organs associated with schistosomiasis. Aracaju - SE, Brazil, 2019.

\begin{tabular}{lcc}
\hline Site & N & p \\
\hline Uterus & 11 & 0.05 \\
Ovary & 5 & 0.11 \\
Ovarian tubes & 1 & 0.44 \\
Vulva & 1 & 0.06 \\
Total & 18 & \\
\hline
\end{tabular}

Table shows characterization of anatomical location of benign tumors in female genital organs associated with schistosomiasis. Source: Author's archive. 
Table 3 showed the types and percentage frequency of some morbidities associated with the presence of female genital schistosomiasis. Of the 75 medical records investigated, the occurrence of salpingitis was the most frequent $(16.0 \%$, p<0.05). Cervical metaplasia and cervicitis had $9.3 \%$ and $6.6 \%$, respectively $(\mathrm{p}<0.05)$.

Table 3 Morbidities associated with female genital schistosomiasis. Aracaju - SE, Brazil, 2019.

\begin{tabular}{lccc}
\hline Pathologies & N & \% & p \\
\hline Salpingitis & 12 & 16.0 & 0.00 \\
Cervical metaplasia & 7 & 9.3 & 0.00 \\
Hemorrhagic corpus luteum & 6 & 8.0 & 0.08 \\
Cervicitis & 5 & 6.6 & 0.00 \\
Without association & 45 & 60.0 & -100.0 \\
Total & 75 & 2 & \\
\hline
\end{tabular}

Table shows characterization of morbidities associated with female genital schistosomiasis. Source: Author's archive.

Figure 2 are photomicrographs of a selected and reviewed case of FSG in the ovary. In Figure 2A, multiple schistosomal granulomas can be seen in the ovary of one of the three samples collected, at different stages of development. These structures were concentrated in the ovarian cortical region, with an inflammatory reaction characterized by the uniform distribution of leukocytes at different points. In Figure 2B, a granuloma in the ovary containing a schistosome egg, in the process of calcification. The keratinized coating appeared to be broken, with several macrophages adhered to its surface and spread over the granuloma. A multinucleated gigantocyte can also be observed, followed by a fibrous capsule. In Figure $2 \mathrm{C}$, an ovarian granuloma in secretory phase with its typical characteristics appears: well-detached fibrotic capsule, acute inflammatory infiltrate with diffuse distribution and evident basophilia of the parasite cells. In Figure 2D shows an ovarian granuloma in the healing phase with signs of fibrosis and the presence of a multinucleated gigantocyte. 
Research, Society and Development, v. 10, n. 7, e47410716652, 2021

(CC BY 4.0) | ISSN 2525-3409 | DOI: http://dx.doi.org/10.33448/rsd-v10i7.16652

Figure 2. Ovary affected by genital schistosomiasis.
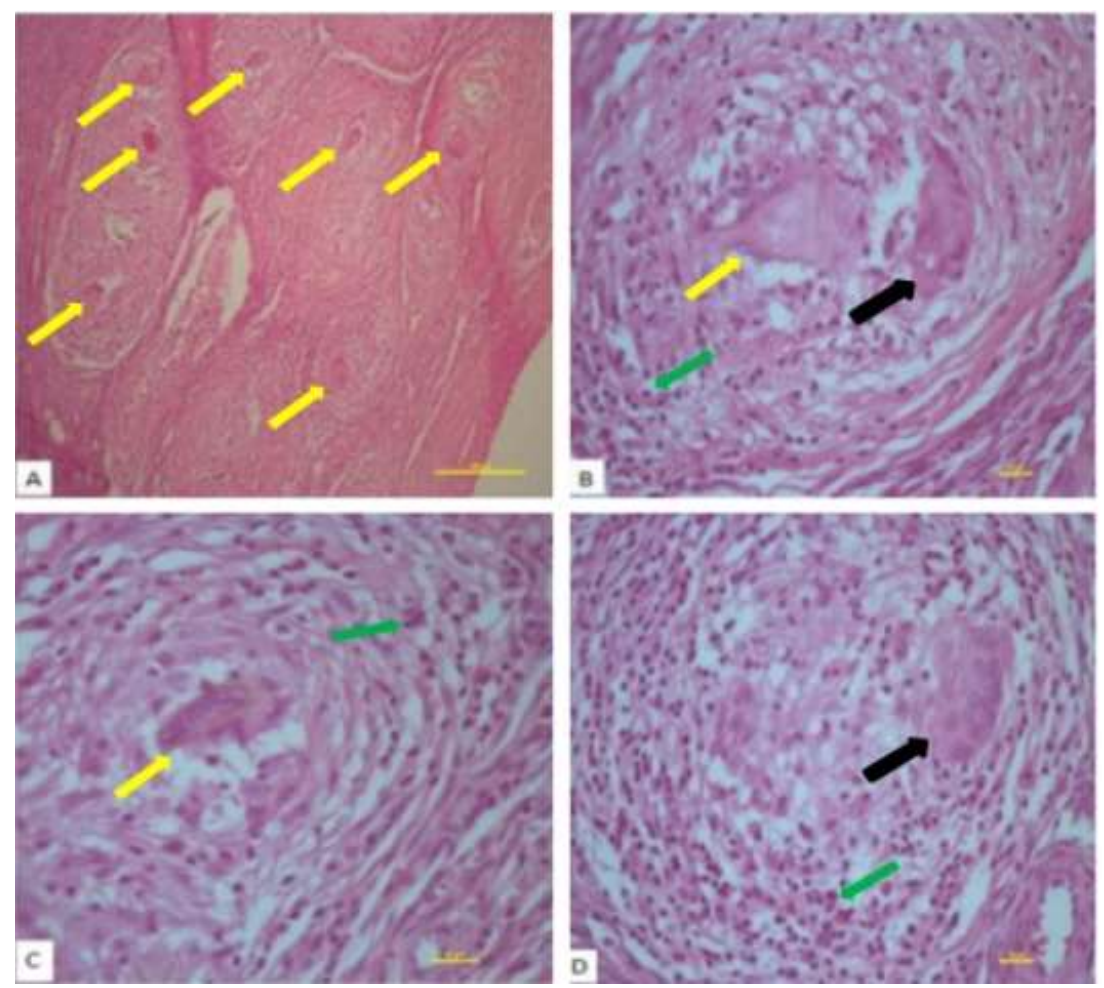

A. Ovarian cortex with granulomatous reaction to Schistosoma mansoni eggs (yellow arrow) (100x). B. Schistosomal granuloma with calcified egg (yellow arrow), multinucleated giant cell (black arrow) and inflammatory cells (green arrow) (400x). C. Schistosomal granuloma in secretory phase, centered by a viable $S$. mansoni egg (yellow arrow), in addition to inflammatory cells (green arrow) (400x). D. Schistosomal granuloma with the presence of fibrosis, multinucleated gigantocyte (black arrow) and inflammatory cells (green arrow) (400x). Hematoxylineosin staining. Source: Author's archive.

Figure 3 showed a fallopian tube affected by schistosomiasis. In 3A, multiple granulomatous formations containing Schistosoma mansoni eggs were visible. In 3B, several S. mansoni eggs can be seen with signs of calcification. In 3C and 3D, these eggs appeared to be calcified and have broken shells, presenting a low intensity inflammatory reaction around them. 
Research, Society and Development, v. 10, n. 7, e47410716652, 2021

(CC BY 4.0) | ISSN 2525-3409 | DOI: http://dx.doi.org/10.33448/rsd-v10i7.16652

Figure 3. Uterine tube affected by schistosomiasis. A and B.
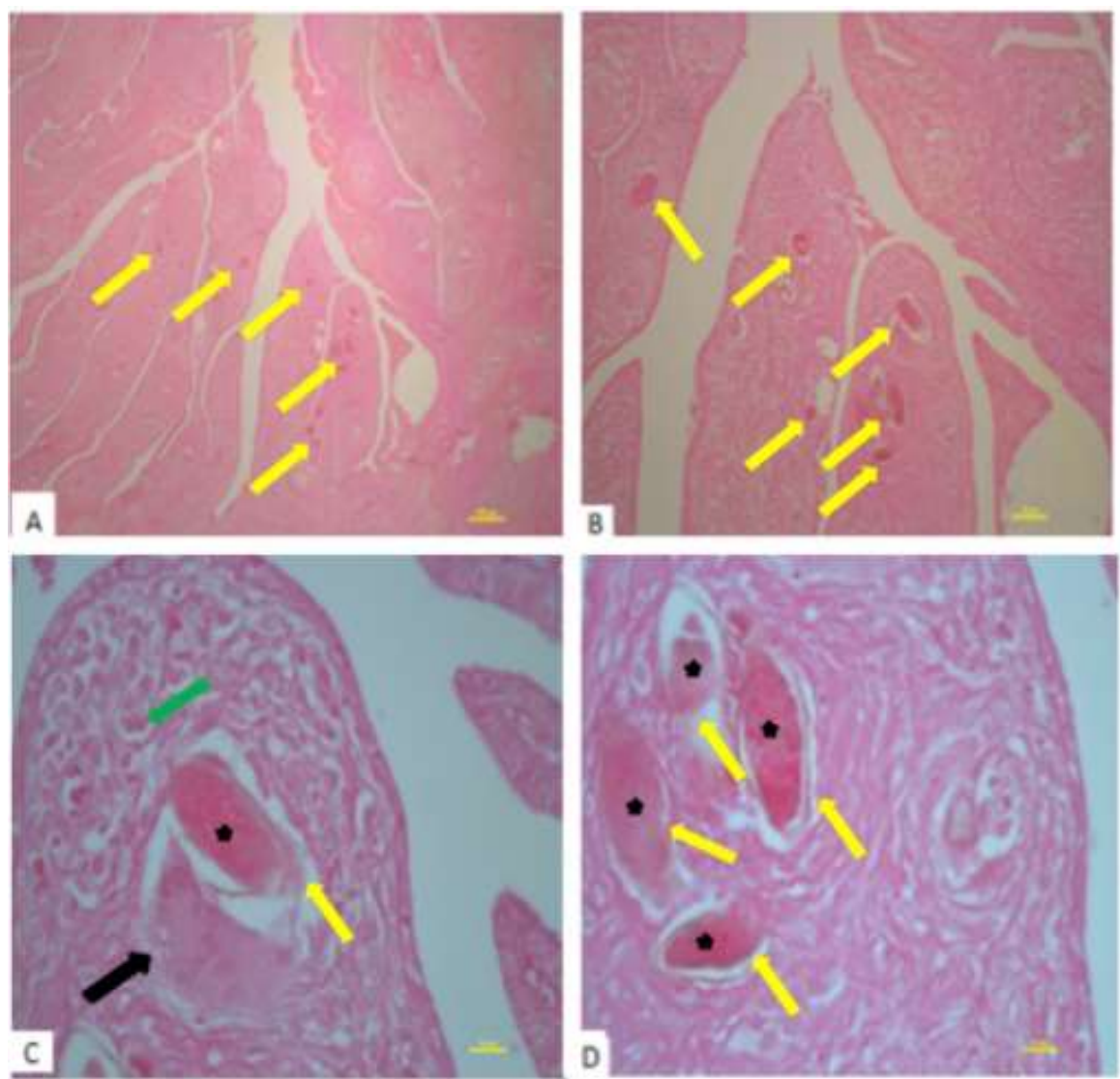

Uterine tube with several schistosomal granulomas (yellow arrow) (40x and 100x, respectively). C. Granuloma with a calcified Schistosoma mansoni egg (yellow arrow). A gigantocyte (black arrow) with a ruptured shell (star) and some inflammatory cells (green arrow) were observed (400x). D. Multiple calcified eggs with little inflammatory reaction (yellow arrow) (400x). Hematoxylin-eosin staining. Source: Author's archive.

In Figure 4, histological sections were stained by Masson's Trichrome and Picrosirius Red, methods used to verify the level of collageinization and type of collagen prevalent in the final stage schistosomal granulomas development. In Figures 4A and $4 \mathrm{~B}$, it was possible to verify the presence of a Schistosoma mansoni egg surrounded by several collagen fibers (stained in blue). In Figures 4C and 4E (without polarization), 4-D and 4-F (with polarization) type I collagen fibers were predominant in the schistosomal granulomas constitution. 
Figure 4. Uterus affected by schistosomiasis. A and B.

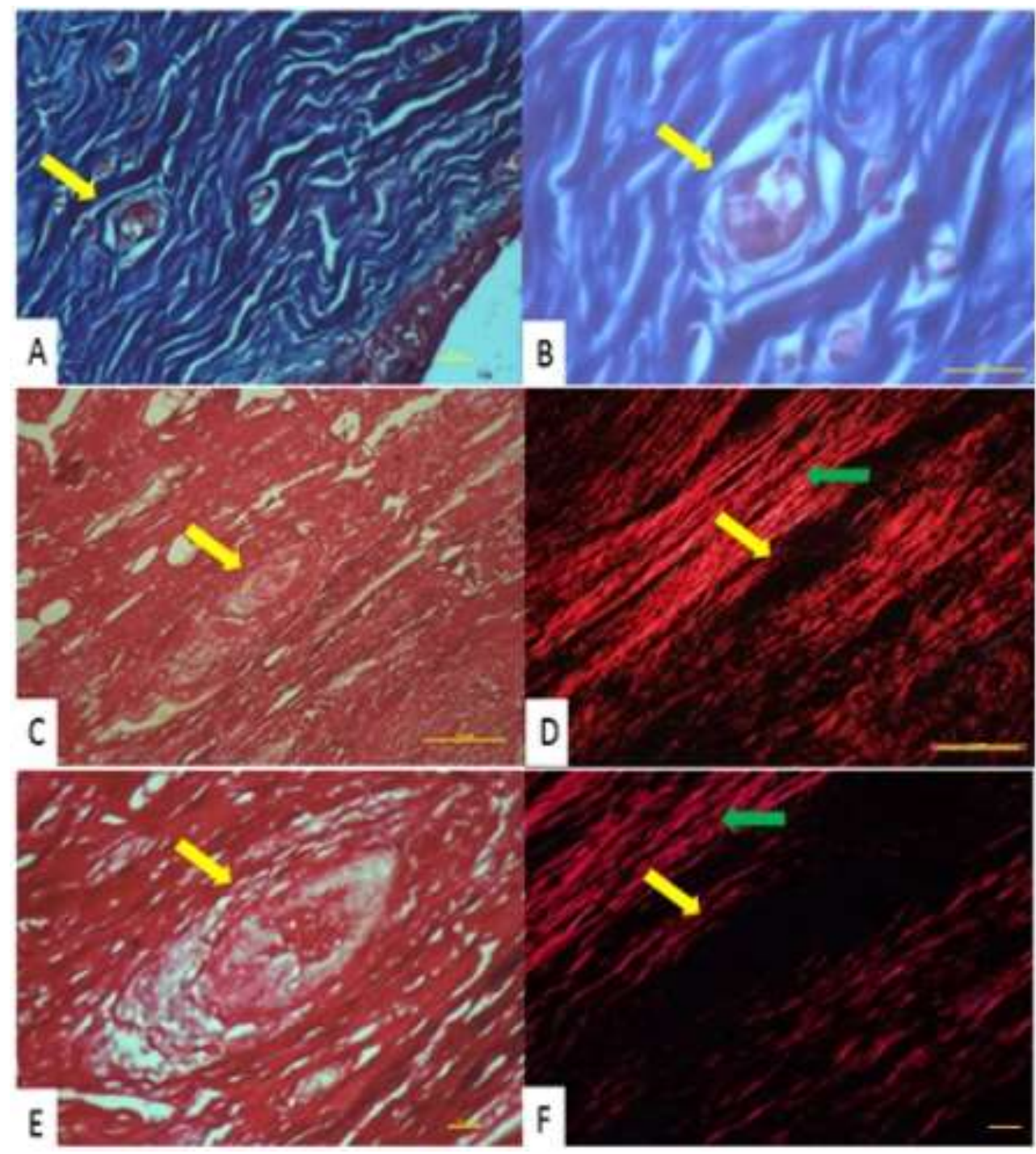

Uterus containing calcified Schistosoma mansoni egg (yellow arrow), surrounded by collagen fiber bundles (400x and 1000x, respectively). Masson's trichrome staining. C and E. Uterus with calcified S. mansoni egg (yellow arrow). (400x and 1000x, respectively). Picrosirius Red staining. D and F. Uterus with a parasite (yellow arrow) surrounded by dense bundles of birefringent collagen fibers, predominantly Type I (green arrow). Scarcity of birefringent collagen fibers inside the egg. (400x and 1000x, respectively). Picrosirius red staining exposed to polarized light. Source: Author's archive.

\section{Discussion}

In its chronic form, schistosomiasis due to $S$. mansoni is a disease responsible for major systemic injuries, mainly in organs such as liver and spleen. These A12 disturbances can cause hepatosplenomegaly, in addition to portal hypertension with ascites (water belly) and, when left untreated, may lead to death (de Souza Gomes et al., 2017). Due to its severity and the growing number of cases in Brazil since the 1970's, the government and the scientific community have been working to promote its elimination, through educational policies regarding the disease and free distribution of Praziquantel (Brasil, 2014).

From 1974 to 1994, 75 cases diagnosed with FGS were found. This finding showed similarity with those from which reported that from 174 people infected with Schistosoma mansoni, in which seven were also diagnosed with FGS. Considering the rarity of ectopic schistosomiasis cases, it can be assumed that information in the literature is insufficient, so there is not enough data available for health professionals to identify this form more effectively. This can lead to erroneous diagnoses and subsequent accidental discoveries such as those reported by(Amorim et al., 2014; Cavalcanti et al., 2011; Faria et al., 2010; 
Poderoso et al., 2008).

Authors such as (Casella et al., 2009; Lambertucci et al., 2009; Lima et al., 2017) reported situations in which women with FGS were incorrectly diagnosed with other pathologies. Incorrect diagnosis can result in ineffective drug treatments and even invasive exploratory surgery, causing women to have their genitals removed unnecessarily. It is important to note that the use of Praziquantel would be sufficient for the death of the parasite; however the damage already caused by the eggs deposited is not reversed (de Souza Gomes et al., 2017). For WHO (2018) (WHO, 2018), Praziquantel is the recommended treatment against all forms of schistosomiasis. Coura and Conceição (2010) (Coura \& Conceição, 2010) reported that Praziquantel is a drug of rapid absorption, used orally and metabolized in the liver, reaching high blood concentrations. Thus, it affects many tissues besides the digestive system, which explains its broad spectrum of action as schistosomicidal and cestocidal.

Several factors have been reported as possible facilitators of female genital schistosomiasis occurrence, highlighting the increase in genital organs vascularization due to hormonal processes, which are more intense during puberty, and monthly during the endometrial cycle (Spezzia, 2018). Thus the parasite can benefit from this greater blood flow to reach the uterus, making it one of the most viable anatomical sites for its installation. In the present study, the uterus was the organ with the second highest occurrence of genital schistosomiasis, a finding also described by (Rato et al., 2017).

According to Neves et al. (2007) (Neves et al., 2007), pregnancy would be considered a risk factor, due to the suppression of the adaptive immune system, as well as the increase in the erythrocyte mass observed in this period. Knowing that the elimination of eggs in feces depends on the action of the immune system to expel them from the mesenteric blood vessels to the intestinal lumen (Schwartz \& Fallon, 2018) and that S. mansoni depends on red blood cells to produce its eggs (Toh et al., 2015), pregnancy would represent a physiological condition favorable to the accumulation of a large quantity of eggs in the body, increasing the chances of their migration to places considered ectopic.

In the present study, the ovary was the anatomical site most affected by schistosomiasis. For (Azeredo et al., 2010), such finding could be justified by the hypothesis that there is a pathological shunt formation between the splenic vein and the left renal vein, in which the latter drains blood from ovarian veins, providing an access pathway to the parasite. Another hypothesis proposed by (Feldmeier et al., 1998) would be the parasite accessibility through anastomoses between the mesenteric veins (upper and lower to the ovarian veins). These two access routes would be viable due to the parasite's ability to move against the bloodstream, thus reaching the richly vascularized ovarian stroma.

These pathways would be possible since, in the chronic schistosomiasis phase with a compensated portal hypertension, there is an increase in the portal circulation pressure due to granulomas formation and eggs embolization in the blood vessels. In order to compensate these obstructions and decrease pressure, blood vessels would increase their caliber, leading to the appearance of abnormal connections between portal and systemic circulation (portosystemic shunts) (Stringer, 2008).

The presence of tumor formations associated with $S$. mansoni eggs has been widely reported in the literature (Amorim et al., 2014; Filho et al., 2010; Lima et al., 2017). In the present study, this association with statistical significance was also found for the uterus ( $\mathrm{p}$ <0.05). (Pinho, 2005) suggested that neoplastic formations would produce substances capable of causing neovascularization, serving as a nutrition source for tumor growth. The benign tumor formations, allow the parasite to use the newly formed vessels as a way of accessing this anatomical site, being, therefore, found associated with tumors, but in the absence of causality between the parasite and the neoplastic formation.

In contrast to other authors (Herman et al., 2017; Tuffour et al., 2018), an association between the metabolites produced by eggs and the appearance of neoplasms would be possible. (Shariati et al., 2011) admitted that schistosomal granulomas formation would increase VEGF (vascular endothelial growth factor) levels, causing the appearance of new blood vessels. This type of alteration is considered as one of the pillars for the formation of neoplasm (Abd El-Aal et al., 2017). 
Cervicitis and cervical metaplasia were present in $11.5 \%$ in $16.2 \%$ of total cases, respectively, and both comorbidities were associated with the parasite presence in the uterus ( $p$ <.05). For (Delmondes et al., 2014), inflammation caused by the parasite in this region may be responsible for some symptoms described by patients, such as menstrual changes and vaginal discharge, and, in extreme cases may be the cause of infertility due to obstruction.

In the present study, an association between schistosomiasis and salpingitis was found (p <0.05). (Feldmeier et al., 1998) suggests that, in some cases, salpingitis caused by the presence of parasite eggs in the ovarian tubes can lead to tubal lumen obstruction, leading to ectopic pregnancy and infertility, as reported by several authors (Badiale et al., 2005; Cabral et al., 1992; Hoffmann \& Bauerfeind, 2003; Rosen \& Kim, 1974). In addition, this inflammation could be associated with the lower abdomen pain described by $13 \%$ of the patients in the analyzed sample.

In the histopathological analysis, the granulomas were in a late or scarred secretory phase, indicating the chronicity of schistosomiasis. This finding highlights the late diagnosis of the disease, corroborating with (de Souza Gomes et al., 2017), who stated that the late diagnosis of FGS can cause serious problems in women's health.

As for collagen analyses on the granulomas observed in this study, the level of collagen fibers deposition increased in the final stages of these lesions development. In the secretory phase, collagen fibers had a loose arrangement while a more compact and dense organization, with a predominance of type 1 collagen fibers, was observed in the healing phase

Gigantocytes were also visualized inside granulomas in the healing phase, corroborating the reports by (MacDonald et al., 2002) and (Nathan, 2012), for whom the synthesis of IL-4, IL-5 and IL-13 by TH-2 lymphocytes occurs during the disease chronic phase. These cytokines promote macrophages chemotaxis to the granulomatous lesions sites, stimulating their fusion to form gigantocytes with a high phagocytic capacity. The macrophages activated by TH-2 secrete substances that stimulate smooth muscles contraction: at the intestinal level this lead to an increase in peristalsis, in an attempt to expel the parasite eggs. However, at a uterine level, such contractions can cause pain in the lower abdomen, as observed in medical records.

In the present study, a low frequency of female genital schistosomiasis cases, from 1974 to 1994, was found. The most affected anatomical sites were the ovary and the uterus. In addition, the parasite presence in the female genital system can facilitate the development of genital inflammatory processes such as salpingitis and cervicitis; pre-malignant lesions such as cervical metaplasia; and tumors such as myomas. In the histopathological analysis, it was possible to observe that Schistosoma mansoni granulomas were in their final stages of development, reflecting the late diagnosis of the disease ectopic form.

Therefore, female genital schistosomiasis is an important risk condition for women's health, deserving better and greater attention from public health policies.

\section{Conclusion}

In the present study, it was found a low frequency of occurrence of cases of female genital schistosomiasis in the period from 1974 to 1994 . The most affected anatomical sites were the ovary and uterus, in addition, the presence of the parasite in the female genital tract may facilitate development inflammatory processes in Organ's genitals, such as salpingitis and cervicitis, as well as premalignant lesions, such as metaplasia of the colon, and tumors such as myoma. In the histopathological analysis, it was observed that S. mansoni granulomas were in the final stages of development, reflecting the late diagnosis of this ectopic modality of the disease. Therefore, female genital schistosomiasis is an important risk condition for women's health, deserving greater attention from public health policies.

\section{Acknowledgements}

We want to thank CAPES for the scholarship granted to Davyson Moraes Leandro through Programa de Pós - 
Graduação em Biologia Parasitária/UFS and Universidade Tiradentes (UNIT), represented by Prof. Dr. Hesmony Santa Rosa and Prof ${ }^{\circ}$. Dr. Francisco Prado Reis, for granting access to the Memorial Prof. Dr. Nestor Piva and for all the contribution given and essential data availability for the study development.

\section{References}

Abd El-Aal, N. F., Hamza, R. S., \& Magdy, M. (2017). Anti-angiogenic and anti-lymphangiogenic role of praziquantel and artemether in experimental mansoniasis. Acta Parasitologica, 62(4), 708-716.

Amorim, A. G., Pagio, F. A. B., Ferreira, R. N., \& Chambô Filho, A. (2014). Genital Schistosomiasis: A Report on Two Cases of Ovarian Carcinomas Containing Viable Eggs of Schistosoma mansoni. Case Reports in Obstetrics and Gynecology, 2014.

Azeredo, L. M., Queiroz, L. C. de, Marinho, C. C., Espírito Santo, M. C. C. do, Chammas, M. C., Ruiz Guevara, R., Prata, A., Antunes, C. M. de F., Lambertucci, J. R., \& Cerri, G. G. (2010). Aspectos ultrassonográficos e hemodinâmicos da esquistossomose mansônica: avaliação pela ultrassonografia Doppler em áreas endêmicas.

Badiale, G. B., Brandão, D. F., \& Ribeiro-Silva, A. (2005). Esquistossomose endocervical. Revista Da Sociedade Brasileira de Medicina Tropical, 38(4), 351352 .

Behmer, O. A., \& Tolosa, E. M. C. de. (2003). Manual de técnicas para histologia normal e patológica. In Manual de técnicas para histologia normal e patológica (p. 331).

Brasil. (2014). Sistema nacional de vigilância em saúde.

Cabral, A. C. V., Miranda, S., \& Monteiro, J. B. (1992). Associaçäo entre salpingite esquistossomótica e gravidez ectópica: relato de um caso. J. Bras. Ginecol, $27-28$.

Casella, M. L., Fanni, V. S. S., Verndl, D. O., Basso, M. C., Mello, L. F., \& Glina, S. (2009). Schistosomiasis mansoni of the bladder simulating bladder cancer: a case report. Revista Da Sociedade Brasileira de Medicina Tropical, 42(5), 581-582.

Cavalcanti, M. G., Gonçalves, M. M. I., Barreto, M. M., da Silva, A. H., Madi, K., Peralta, J. M., \& Igreja, R. P. (2011). Genital schistosomiasis mansoni concomitant to genital tumor in areas of low endemicity: challenging diagnosis. The Brazilian Journal of Infectious Diseases, 15 (2), $174-177$.

Coura, J. R., \& Conceição, M. J. (2010). Specific schistosomiasis treatment as a strategy for disease control. Memórias Do Instituto Oswaldo Cruz, 105(4), 598603.

Oliveira, A. D. S., Silva, J. R. S., dos Santos, R. L. C., Reis, F. P., \& Feitosa, V. L. C. (2020). Challenges in schistosomiasis control in Sergipe, Brazil: from 2013 to 2018. Research, Society and Development, 9(10), e3679108802-e3679108802.

Oliveira, A. P., de Aguiar, E. S., \& Pontes, A. N. (2020). Doenças tropicais negligenciadas e as vulnerabilidades socioambientais nas capitais amazônicas. Research, Society and Development, 9(9), e502997502-e502997502.

Souza Gomes, E. C., Domingues, A. L. C., de Aguiar Júnior, F. C. A., \& Barbosa, C. S. (2017). Ovarian Manson's schistosomiasis: rare diagnosis or underestimated prevalence? Revista Brasileira de Ginecologia e Obstetrícia/RBGO Gynecology and Obstetrics, 39(05), $249-254$.

Delmondes, L. M., Cruz, M. A. F., Guimarães, M. K. H., Santana, L. G., Gonçalves, V. P. C., \& Brito, H. L. de F. (2014). Esquistossomose endocervical: relato de caso. Revista Brasileira de Ginecologia e Obstetrícia, 36(6), 276-280.

Santos, C. M. A., de Oliveira Santos, L. S., dos Santos, J. A., dos Santos Silva, E., dos Santos, M. H., Da Silva, D. K., de Souza Santos, J. F., de Oliveira Subrinho, D., dos Santos, C. K. A., \& dos Santos, C. B. (2019). Comparativo e perfil dos infectados em esquistossomose no estado de Alagoas entre 2016 e 2017. PUBVET, 13, 153 .

Faria, C. A., Conceicao, J. C. J., Valadares, T. F., Rodrigues, B., \& Carneiro, L. (2010). Schistosoma mansoni: a rare cause of tubal infection. Brazilian Journal of Infectious Diseases, 14(3), 288-290.

Feldmeier, H., Daccal, R. C., Martins, M. J., Soares, V., \& Martins, R. (1998). Genital manifestations of schistosomiasis mansoni in women: important but neglected. Memórias Do Instituto Oswaldo Cruz, 93, 127-133.

Filho, A. C., Neves, R. F., Gusmão, C. B., Saade, F. T. P., Dalvi, I. R., \& Leo, T. C. (2010). Genital schistosomiasis: mucinous cystadenocarcinoma of the ovary containing schistosoma mansoni eggs. The Journal of Tropical Medicine and Parasitology, 33(1), 36-40.

Herman, A. M., Kishe, A., Babu, H., Shilanaiman, H., Tarmohamed, M., Lodhia, J., Amsi, P., Pyuza, J., Mremi, A., \& Mwasamwaja, A. (2017). Colorectal cancer in a patient with intestinal schistosomiasis: a case report from Kilimanjaro Christian Medical Center Northern Zone Tanzania. World Journal of Surgical Oncology, 15(1), 146.

Hoffmann, H., \& Bauerfeind, I. (2003). High tissue egg burden mechanically impairing the tubal motility in genital schistosomiasis of the female. Acta Obstetricia et Gynecologica Scandinavica, 82(10), 970-971.

Lambertucci, J. R., Villamil, Q. T. M. F., Savi, D., \& Dias, I. C. (2009). Genital schistosomiasis mansoni: tubal tumor and parietal peritoneum involvement diagnosed during laparoscopy. Revista Da Sociedade Brasileira de Medicina Tropical, 42(5), 583-586.

Lima, C. W. R., Oliveira, N. M. C. de, Silva, S. V. D. da, Duarte, M. E. L., \& Barbosa, A. P. F. (2017). Ectopic forms of schistosomiasis mansoni in the second 
Research, Society and Development, v. 10, n. 7, e47410716652, 2021 (CC BY 4.0) | ISSN 2525-3409 | DOI: http://dx.doi.org/10.33448/rsd-v10i7.16652

macroregion of Alagoas: case series report and review of the literature. Revista Da Sociedade Brasileira de Medicina Tropical, 50(6), 812-818.

MacDonald, A. S., Araujo, M. I., \& Pearce, E. J. (2002). Immunology of parasitic helminth infections. Infection and Immunity, 70(2), $427-433$.

Nathan, C. (2012). Secretory products of macrophages: twenty-five years on. The Journal of Clinical Investigation, 122(4), 1189-1190.

Neves, C., Medina, J. L., \& Delgado, J. L. (2007). Alterações endócrinas e imuno-modulação na gravidez. Arquivos de Medicina, 21 (5-6), 175-182.

Pinho, M. S. L. (2005). Angiogênese: o gatilho proliferativo. Revista Brasileira de Coloproctologia, 25 (4), 396 -402.

Poderoso, W. L. S., Santana, W. B. de, Costa, E. F. da, Cipolotti, R., \& Fakhouri, R. (2008). Ectopic schistosomiasis: description of five cases involving skin, one ovarian case and one adrenal case. Revista Da Sociedade Brasileira de Medicina Tropical, 41(6), 668-671.

Rato, I., Pinto, L., Reis, I., Bernardino, M., \& Jorge, A. F. (2017). Tumor anexial na gravidez: como abordar? Acta Obstétrica e Ginecológica Portuguesa, 11(2), $113-121$.

Rosen, Y., \& Kim, B. (1974). Gestação tubária associada à salpingite por Schistosoma mansoni. Obstetrícia e Ginecologia, $43,413-417$.

Santos, S. S. B. da S., \& Melo, C. M. M. de. (2008). Avaliação da descentralização da vigilância epidemiológica para a equipe de saúde da família. SciELO Public Health.

Schwartz, C., \& Fallon, P. G. (2018). Schistosoma “eggs-iting” the host: granuloma formation and egg excretion. Frontiers in Immunology, 9, 2492.

Shariati, F., Perez-Arellano, J. L., Carranza, C., Lopez-Aban, J., Vicente, B., Arefi, M., \& Muro, A. (2011). Evaluation of the role of angiogenic factors in the pathogenesis of schistosomiasis. Experimental Parasitology, 128(1), 44-49.

Sousa, F. das C. A., Soares, H. V. A., Lemos, L. E. A. S., Reis, D. M., da Silva, W. C., \& de Sousa Rodrigues, L. A. (2020). Perfil epidemiológico de doenças negligenciadas de notificação compulsória no Brasil com análise dos investimentos governamentais nessa área. Research, Society and Development, 9(1), e62911610-e62911610.

Spezzia, S. (2018). Alterações periodontais na adolescência. Periodontia, 43-47.

Stringer, M. D. (2008). The clinical anatomy of congenital portosystemic venous shunts. Clinical Anatomy: The Official Journal of the American Association of Clinical Anatomists and the British Association of Clinical Anatomists, 21(2), 147-157.

Team, R. C. (2020). R: A language and environment for statistical computing. Vienna, Austria.

Toh, S. Q., Gobert, G. N., Malagón Martínez, D., \& Jones, M. K. (2015). Haem uptake is essential for egg production in the haematophagous blood fluke of humans, Schistosoma mansoni. The FEBS Journal, 282(18), 3632-3646.

Tuffour, I., Ayi, I., Gwira, T. M., Dumashie, E., Ashong, Y., \& Appiah-Opong, R. (2018). Schistosoma egg antigen induces oncogenic alterations in human prostate cells. Analytical Cellular Pathology, 2018.

Weerakoon, K. G. A. D., Gobert, G. N., Cai, P., \& McManus, D. P. (2015). Advances in the diagnosis of human schistosomiasis. Clinical Microbiology Reviews, 28(4), 939-967.

Weerakoon, K. G., Gordon, C. A., \& McManus, D. P. (2018). DNA diagnostics for schistosomiasis control. Tropical Medicine and Infectious Disease, 3(3), 81.

WHO, W. H. O. (2018). Estimativas de saúde global 2016: óbitos por causa, idade, sexo, por país e por região, $2000-2016$. 